\title{
Forest Humus Type Governs Heavy Metal Accumulation in Specific Organic Matter Fractions
}

\author{
Jarosław Lasota • Ewa Błońska • \\ Stanisław Lyszczarz $・$ Mark Tibbett
}

Received: 7 October 2019 / Accepted: 31 January 2020 /Published online: 8 February 2020

(C) The Author(s) 2020

\begin{abstract}
Soils have the potential to accumulate heavy metals and the capacity to do so is strongly related the properties of each soil. Soil organic matter is a key factor in the retention, release, and bioavailability of heavy metals, and here we have determined the accumulation of heavy metals in various types of humus in the Rybnik Forest District in southern Poland. In a novel approach, we analyzed relationships between heavy metals within soil organic matter fractions and evaluated the role of organic fractions in mediating metal mobility. Specifically, we tested whether (i) the type of forest humus determines the heavy metal accumulation; (ii) heavy metals accumulation is associated with soil organic matter fractions; and (iii) heavy metals have an inhibitory influence on biochemical properties especially enzymes activity in different humus types. Four types of humus were sampled (mor, moder, moder-mull, mull), physically fractioned, and a number of chemical and biochemical properties were analyzed. Calculated geoaccumulation index $\left(I_{\text {geo }}\right)$ and enrichment factor $(\mathrm{EF})$
\end{abstract}

Electronic supplementary material The online version of this article (https://doi.org/10.1007/s11270-020-4450-0) contains supplementary material, which is available to authorized users.

J. Lasota $\cdot$ E. Błońska $(\bowtie) \cdot$ S. Łyszczarz

Department of Ecology and Silviculture, Faculty of Forestry, University of Agriculture, Al. 29 Listopada 46, Krakow, Poland e-mail: eblonska@ar.krakow.pl

M. Tibbett

Department of Sustainable Land Management and the Soil Research Centre, School of Agriculture, Policy and Development, University of Reading, Reading RG6 6AR, UK confirmed soil pollution with $\mathrm{Cd}$ and $\mathrm{Pb}$. The type of humus differed in the accumulation of heavy metals, which is associated to the variable concentration of organic matter remaining at each decay class. We found no relationship between enzymatic activity and heavy metals concentration except for a positive correlation between urease activity and nickel concentration. Considering wider evidence, we propose a biogeochemical link between nickel deposition and the production of soil-borne urease in these forest soils.

Keywords Enzyme activities · Forest soil · Light and heavy fraction of soil organic matter

\section{Introduction}

Soil has the capacity to accumulate trace elements such as heavy metals. The potential to accumulate metals is determined by the soil's sorption properties, which is regulated by soil texture, organic matter, mineralogy, $\mathrm{pH}$, water content, and temperature; along with the unique properties of each metal ion (Dube et al. 2001; Wang 2008; Quenea et al. 2009; Pająk et al. 2016; Kuźniar et al. 2018). Soil organic matter (SOM) and clay minerals are the main component of soil that possess significant sorption capacity relative to metals through exchange sorption, complexing, or chelation. Soil organic matter is involved in retention, reduction of mobility, and reduction of bioavailability of heavy metals (Impellitteri et al. 2002; Wolińska et al. 2018). The heterogeneous nature of SOM includes particles 
with components that vary considerably in their turnover rates (von Lützow et al. 2007).

A number of methods exist to physically fractionate SOM (Duddigan et al. 2019), and density fractionation is commonly used to separate SOM into three fractions that are characterized by different degrees of stability (von Lützow et al. 2007; Marschner et al. 2008; Wambsganss et al. 2017). Soil organic matter can be divided into labile fraction also called free light fraction (fLF), mineral soil light fraction which may become stabilized by occlusion inside aggregates (so-called occluded light fraction-oLF), and stabilized fraction of SOM, also known as heavy fraction which is mineralassociated fraction (MAF) (von Lützow et al. 2007; Błońska et al. 2017). Labile $\mathrm{C}$ can remain in the ground from a week to years and recalcitrant $\mathrm{C}$ can persist for decades or even centuries. SOM associated with minerals can be stabilized due to its protection from mineralization ( $\mathrm{Li}$ et al. 2019), whereas the light fraction is more susceptible to changes to soil use and altered litter inputs (Grüneberg et al. 2013; Błońska et al. 2017).

Forest ecologist identifies three types of humus: mull, mor, and moder depending on the degree of decomposition and integration with mineral matter, acidity, and base content (Osman 2013). Mor type humus is formed under the conditions of low biological activity in the soil, when the organic matter mineralization occurs at a slow rate. Mull is a wellhummified organic matter and it is associated with high biological activity. Moder is an intermediate form of humus between mull and mor (Lasota and Błońska 2013; Zaiets and Poch 2016). The soil microbial biomass is the main driving force for the decomposition of organic matter, and it is frequently utilized as an index of changes of soil properties resulting from land management change and environmental stressors (Baaru et al. 2007). The primary mode of action of the microbial biomass is the exudation of enzymes that are responsible for the turnover and release of carbon and nutrients (Gougoulias et al. 2014; Falkowski et al. 2008). Consequently, an assessment of soil biochemistry, closely related to soil microbial activity, is essential to draw salient conclusions on soil organic matter and metal accumulation, especially if enzyme activity is inhibited (Brookes 1995; Lee et al. 2002; Wang et al. 2007; Błońska et al. 2016; Kuźniar et al. 2018).

In Poland, soils contaminated with heavy metals are primarily found in industrial areas (Karczewska and
Kabała 2010; Kuźniar et al. 2018). The influence on contamination with heavy metals on arable soils as a result of anthropogenic activities has been well studied (Kelepertzis 2014; Tóth et al. 2016; Marrugo-Negrete et al. 2017), while forest soils have received less attention. Due to the strong binding force of the majority of heavy metals by the sorption complex of forest soils, the state of contamination remains stable for a long period, even after the cessation of the pollution source. Given the likely high residual contamination load, our overarching objective was to determine the accumulation of heavy metals in various types of humus in forest stand in a region with antecedent high metalliferous dust depositions. In a novel approach, we analyze relationships of heavy metals with soil organic matter fractions and evaluate the role of these organic fractions in metal mobility. We have tested the following hypotheses: (1) the type of forest humus determines the heavy metal accumulation; (2) heavy metals accumulation is associated with specific soil organic matter fractions; (3) heavy metals have an inhibitory influence on biochemical properties especially enzymes activity in different humus types.

\section{Materials and Methods}

\subsection{Study Area and Soil Sampling}

The study area is located in the Rybnik Forest District $\left(50^{\circ} 6^{\prime} 40.56 \mathrm{~N} ; 18^{\circ} 33^{\prime} 54.28 \mathrm{E}\right)$, in the Upper Silesian Industrial Region, Poland (Fig. S1). The field sites are in the immediate vicinity of industrial plants (steelworks, mines, coking plants, power plants), which emitted harmful pollutants since the beginning of the nineteenth century. The dust formed in the process of coal combustion at the Rybnik power plant contains on average $120 \mathrm{mg} \mathrm{kg}^{-1} \mathrm{Zn}, 64 \mathrm{mg} \mathrm{kg}^{-1} \mathrm{Cr}, 40 \mathrm{mg} \mathrm{kg}^{-1}$ of each $\mathrm{Cu}, \mathrm{Ni}$, and $\mathrm{Pb}$ and $3 \mathrm{mg} \mathrm{kg}^{-1} \mathrm{Cd}$ (Smołka-Danielowska 2006). The elevated content of heavy metals in the soils of the study site has been confirmed by earlier research (Magiera et al. 2015; Magiera et al. 2016). The field sites were located in forest complex east of Rybnik where the soils are derived from glacial moraines and are dominated by Brunic Arenosols and Cambisols (WRB 2014). The mean annual temperature of the area is $8.4{ }^{\circ} \mathrm{C}$, with a mean annual precipitation of $705 \mathrm{~mm}$, and a growing season of 235 days.

Twenty field plots were selected, representing various types of forest humus, i.e., mor, moder, 
moder-mull, and mull. The dominant tree species were pine (Pinus sylvestris) and oak (Quercus petraea) on the areas with mor type humus with the remainder dominated by oak (Quercus petraea). Each of the four types of humus was sampled 5 times at different locations, giving a total of five replicate samples each. In order to ensure clay content did not confound our results, we selected sites with a uniform texture (loamy sand: sand $76 \%$, silt $19 \%$, clay 5\%). For sampling, a small soil pit was dug and the horizon sequence was verified for the soil type. The type of humus was determined on each of 20 test areas based on morphology. For each test area, three samples to the depth of $30 \mathrm{~cm}$ were collected for laboratory analyses. The samples were collected from horizons according to the sequence found in the profile (Fig. S2). In the case of an area with mor type humus, these were Of, Oh, AE; for moder humus: Ofh, $\mathrm{Ah}$, and $\mathrm{AB}$; and for modermull humus: oLF, Ah, and AB. On the area with mull type humus, the sequence of horizons collected was $\mathrm{Ah}, \mathrm{A}$, and $\mathrm{AB}$. In all the cases, the samples for the study were collected from 4 sub-stands of soil. For determination of biochemical properties, fresh samples of natural moisture were sieved through a sieve $(<2 \mathrm{~mm})$ and stored at $4{ }^{\circ} \mathrm{C}$ before analysis. All samples were collected in June 2018.

\subsection{Laboratory Analysis of Soil}

Field fresh soil samples were dried and sieved through 2-mm mesh. The properties of the soil samples were determined using common pedological methods (Pansu and Gautheyrou 2006). The particle size distribution was determined using laser diffraction (Analysette 22, Fritsch, Idar-Oberstein, Germany). Soil $\mathrm{pH}$ was determined in $\mathrm{H}_{2} \mathrm{O}$ and $\mathrm{KCl}$ using the potentiometric method. Carbon (C) and nitrogen $(\mathrm{N})$ were measured with an elemental analyzer (LECO CNS TrueMac Analyzer (Leco, St. Joseph, MI, USA)). Exchangeable aluminum (Al) was determined by the Sokołow method and hydrolytic acidity by the Kappen method (Ostrowska et al. 1991). The concentration of cations and content of $\mathrm{Cd}, \mathrm{Cr}, \mathrm{Cu}, \mathrm{Ni}, \mathrm{Pb}$, and $\mathrm{Zn}$ was determined by an ICP (ICP-OES Thermo iCAP 6500 DUO, Thermo Fisher Scientific, Cambridge, U.K.). The content of $\mathrm{Cd}, \mathrm{Cr}, \mathrm{Cu}, \mathrm{Ni}, \mathrm{Pb}$, and $\mathrm{Zn}$ was determined after mineralization in the mixture of concentrated nitric acid and perchloric at the ratio $2: 1$. Sum of base cations (BC) was calculated.

Physical separation of soil organic matter fractions was performed using the method described by Sohi et al. (2001). A sample of soil (15 g) was placed in a 200-ml centrifuge tube and $90 \mathrm{ml}$ of NaI $\left(1.7 \mathrm{~g} \mathrm{~cm}^{-3}\right)$ was added. Each tube was gently shaken for $1 \mathrm{~min}$ and centrifuged for $30 \mathrm{~min}$. The free light fraction (fLF) was removed using the pipette and collected on a glass fiber filter. The soil remaining at the bottom of the centrifuge tubes was mixed with another portion of $90 \mathrm{~mL}$ of $\mathrm{NaI}$ and subjected to sonication (60 watts for $200 \mathrm{~s}$ ) to destroy aggregates. After centrifugation, the matter released from aggregates occluded light fraction (oLF) was collected on glass fiber filter. The remaining fraction was assumed to consist of mineral associated fraction (MAF) of SOM. After drying $\left(40{ }^{\circ} \mathrm{C}\right)$, the subsamples of different fraction were weighted and analyzed for $\mathrm{C}_{\mathrm{fLF}}, \mathrm{C}_{\mathrm{oLF}}$, and $\mathrm{C}_{\mathrm{MAF}}$, respectively using an LECO CNS True Mac Analyzer (Leco, St. Joseph, MI, USA).

Dehydrogenase activity (DHA) was determined by the reduction of 2,3,5-triphenyltetrazolium chloride (TTC) to triphenyl formazan (TPF) using Lenhard's method according to the Casida procedure (Alef and Nannipieri 1995). Urease activity (UR) was determined according to Tabatabai and Bremner (1972). To determine microbial biomass carbon (MBC) and nitrogen (MBN), $5 \mathrm{~g}$ of soil was weighed and fumigated with $\mathrm{CHCl}_{3}$ in an exsiccator for $24 \mathrm{~h}$ at $25{ }^{\circ} \mathrm{C}$. Fumigated and non-fumigated samples were extracted with $0.5 \mathrm{M} \mathrm{K}_{2} \mathrm{SO}_{4}$ and then filtered with the Whatman filters (Vance et al. 1987). The amount of organic $\mathrm{C}$ and $\mathrm{N}$ in soil and deadwood was determined quantitatively (Błońska 2015).

\subsection{Soil Pollution Index}

The geo-accumulation index $\left(I_{\text {geo }}\right)$ and enrichment factor $(\mathrm{EF})$ were calculated to evaluate the degree of pollution different humus type:

$I_{\text {geo }}=\log _{2}\left[\frac{C}{1.5 B}\right]$

where $C$ is the content of a measured heavy metal in soil, $B$ is the content of a given heavy metal in a bedrock or geochemical background, and the factor 
1.5 reflects natural fluctuations of a given heavy metal content in the environment.

$\mathrm{EF}=\frac{\left[\left(\frac{C}{\mathrm{Fe}}\right)\right] \text { sample }}{\left[\left(\frac{C}{\mathrm{Fe}}\right)\right] \text { background }}$

where $\left[\left(\frac{C}{\mathrm{Fe}}\right)\right]$ sample is the ratio of heavy metal and iron content in the soil sample, and $\left[\left(\frac{C}{\mathrm{Fe}}\right)\right]$ background is the ratio of heavy metal and iron content in the geochemical background. Both local as well as reference backgrounds given by KabataPendias (2011) were used to calculate background values for $I_{\text {geo }}$ and $\mathrm{EF}$ in this study.

\subsection{Statistical Analysis}

Principal components analysis (PCA) method was used to evaluate the relationships between different humus type properties. Pearson correlation coefficients between heavy metal content and biochemical properties and soil organic matter were also calculated. Properties of different humus types were compared using a parametric honestly significant difference (HSD) test. The multiple regression method was used to develop models describing the relationship between the heavy metals content and humus characteristics. All the statistical analyses were performed with Statistica 12 software (2012).

\section{Results}

The $\mathrm{pH}$ of the tested humus types ranged from 3.64 to 5.31, the highest acidity found in mull humus and the lowest in the mor humus (Table 1). A statistically significant $\mathrm{pH}$ difference was recorded between mull humus and the remaining humus types. Carbon contents in the profile declined rapidly with horizon depth. The greatest carbon concentration was found in the mor humus $(33.32 \%)$ and the lowest in mull humus (4.14\%) (Table 1). Profile patterns similar to carbon were found for nitrogen concentrations; however, humus $\mathrm{C} / \mathrm{N}$ ratio did vary with widest ratio of $>20$ found in the mor, moder, and moder-mull humus, and a $\mathrm{C} / N<$ 20 were found for mull humus (Table 1). Moder-mull humus was characterized by the most favorable $\mathrm{Ca}: \mathrm{Al}$ ratio, (86.02) and was significantly higher $(p<0.05)$ than the values obtained for mor humus (mean 3.02) (Table 1). In addition, significant differences in hydrolytic and exchange acidity were found among humus types. There were no differences in base cations content. The highest $\mathrm{Cd}$ contents were found in all horizons of mull humus type $\left(1.75,1.17\right.$, and $0.66 \mathrm{mg} \mathrm{kg}^{-1}$, respectively) and in the $\mathrm{Oh}$ horizon of mor humus type (0.99 mg kg-1) (Table 1). Cr was characterized by a comparable concentration in the surface horizon of all humus types $\left(13.78-22.15 \mathrm{mg} \mathrm{kg}^{-1}\right)$; in the second horizon, significantly higher $\mathrm{Cr}$ content was found in mor and in the third horizon of mull humus type. The highest $\mathrm{Cu}$ accumulation was observed for surface horizons of mor and moder humus (26.58 and $26.90 \mathrm{mg} \mathrm{kg}^{-1}$, respectively) and in the deeper $\mathrm{Oh}$ horizon of mor humus $\left(51.57 \mathrm{mg} \mathrm{kg}^{-1}\right)$. The surface horizons of moder-mull and mull humus types were characterized by significantly lower $\mathrm{Cu}$ concentration $(p<0.05)$. Mn exhibited the highest concentrations in all horizons of mull humus, significantly higher than concentrations found in the remaining humus types $(p<0.05)$. The highest Ni concentration was recorded in the surface horizons of mor and moder humus type and in the second horizon of mor humus type. $\mathrm{Pb}$ was characterized by the highest concentration in subsurface horizons in mor, moder, and moder-mull humus (the mean values were 216.92, 115.56, and $92.52 \mathrm{mg} \mathrm{kg}^{-1}$, respectively), in comparison with surface horizons, where no significant difference in the concentration of this metal could be discerned (concentrations from 51.11 to $71.62 \mathrm{mg} \mathrm{kg}^{-1}$ ). The highest $\mathrm{Zn}$ concentration was observed for surface horizon in moder-mull $\left(88.16 \mathrm{mg} \mathrm{kg}^{-1}\right)$, which was significantly higher than $\mathrm{Zn}$ concentration in moder. In the second horizon of mor ( $\mathrm{Oh}$, high concentration of $\mathrm{Zn}$ was found (108.10 $\mathrm{mg} \mathrm{kg}^{-1}$ ); however, the difference in comparison with the remaining types of humus turned out to be insignificant (Table 1).

The highest dehydrogenase activity was estimated in the upper horizon of moder-mull humus (mean $51.31 \mu \mathrm{mol}$ TPF $\left.\mathrm{kg}^{-1} \mathrm{~h}^{-1}\right)$, significantly $(p<0.05)$ higher than the activity of the first horizon of mor humus (mean $8.68 \mu$ mol TPF $\mathrm{kg}^{-1} \mathrm{~h}^{-1}$ ) (Table 2). Urease activity reached the highest level in the upper horizon of the moder humus (mean $67.43 \mathrm{mmol} \mathrm{NNH}_{4} \mathrm{~kg}^{-1} \mathrm{~h}^{-1}$ ) which differed significantly from activity of urease in mull humus $(p<0.05)$. In deeper horizons, no significant differences in the activity of dehydrogenase and urease could be found (Table 2). Microbial biomass 


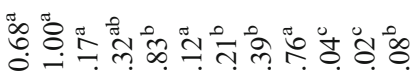

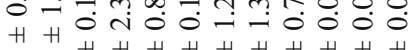

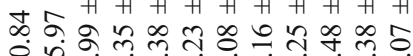
을

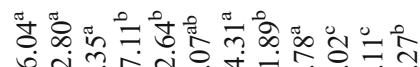
ن H H H H H H H H H

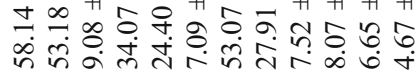

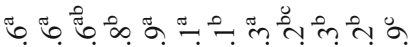

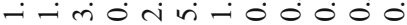
H H H H H H H H H H H H

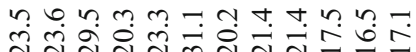

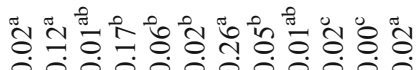
$\because 0 \div 000000000$ H H H H H H H H H H H H

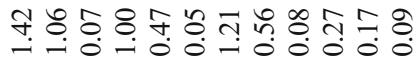

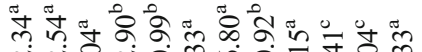
4 40.40000000

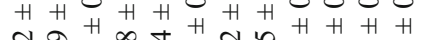

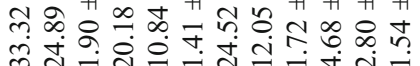

$m$ m-i

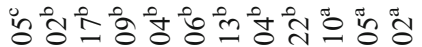
00.00000000000 H H H H H H H H H H H H 絮

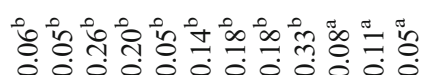
H H H H H H H H H H H H ț

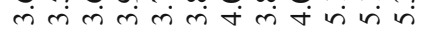

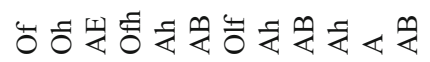
(1)

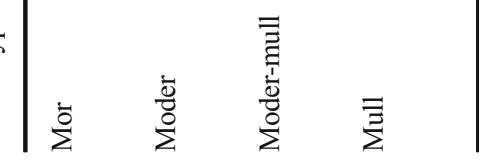

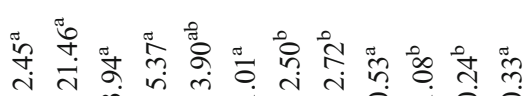

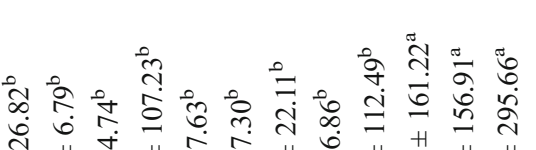

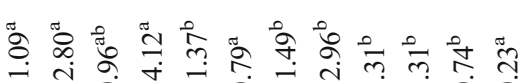
б.

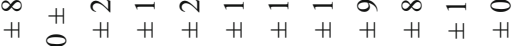

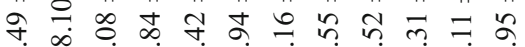
รี 응

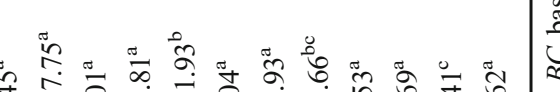

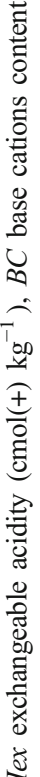
H \begin{tabular}{llllllllll}
$H$ & $H$ & $H$ & $H$ & $H$ & $H$ & $H$ & $H$ & $H$ & $H$ \\
\hline
\end{tabular}

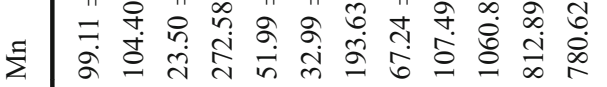
H H $\begin{array}{lllllllll} & H & H & -H & H & 0 & - & 0 & 0 \\ 0\end{array}$ ?

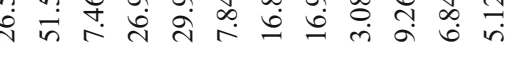

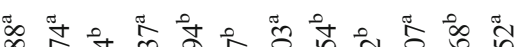

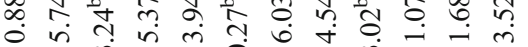
H H $m+H$ H 0 H H $m$ H H H

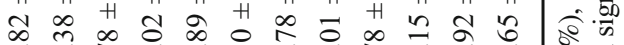

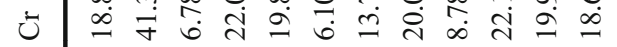
ฮ ซอำ

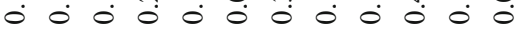
H H H H H H H H ธิ่)

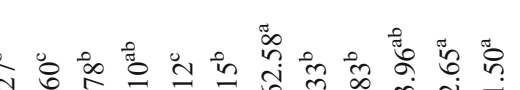
- $0-\dot{0} 000$ त

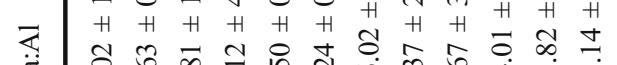

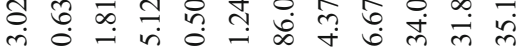
$z$ 里 ก 苞䓪

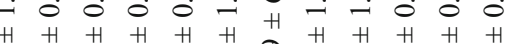
ठั. हี 0.

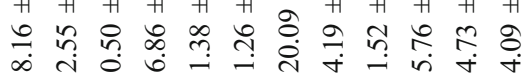
$\infty$ 


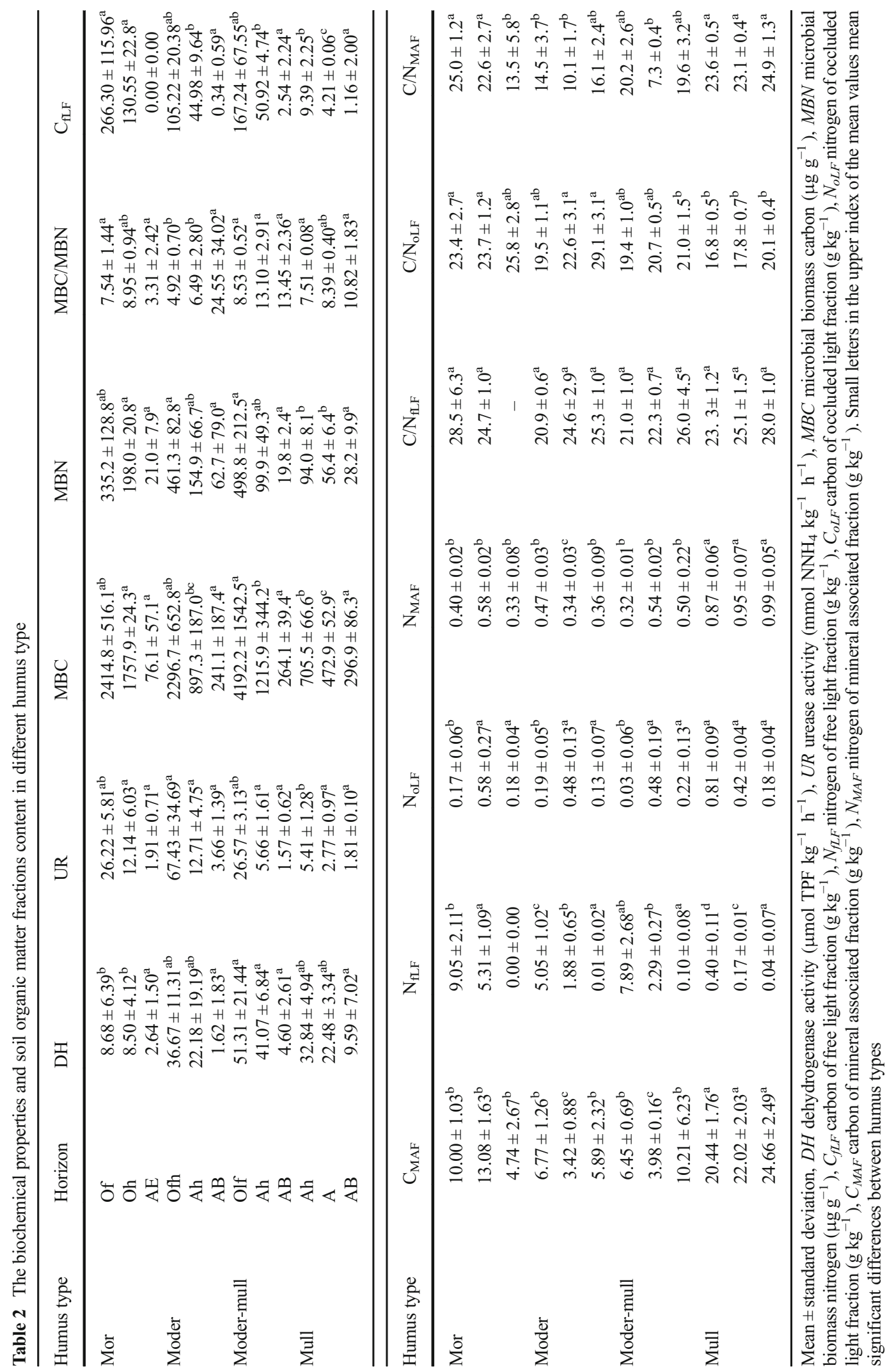


carbon $(\mathrm{MBC})$ in the profile declined rapidly with horizon depth, with typically close to half the MBC found in the second horizon compared to the surface humus. The largest MBC was in the surface moder-mull horizon (4192.2 $\mu \mathrm{g} \mathrm{g}^{-1}$ ), significantly higher than the in mull soil which had the smallest biomass $\left(705.5 \mu \mathrm{g} \mathrm{g}^{-1}\right)$. In the second horizon, the largest MBC found in the mor $\left(1757.9 \mu \mathrm{g} \mathrm{g}^{-1}\right)$. In the third horizon, no significance was found. Microbial biomass nitrogen followed the MBC patterns closely expect the highest values which were found in the surface horizons of moder and modermull. The highest $\mathrm{C}_{\mathrm{fLF}}$ and $\mathrm{N}_{\mathrm{fLF}}$ content characterizes the surface Of horizon in mor humus type (266.30 and $9.05 \mathrm{~g} \mathrm{~kg}^{-1}$, respectively) and oLF horizon in modermull humus type (235.47 and $11.11 \mathrm{~g} \mathrm{~kg}^{-1}$ respectively) $(p<0.05)$ (Table 2). The lowest $\mathrm{C}_{\mathrm{fLF}}$ and $\mathrm{N}_{\mathrm{fLF}}$ content characterizes the surface horizon of mull humus type (9.39 and $0.40 \mathrm{~g} \mathrm{~kg}^{-1}$ respectively). In the case of the second horizon, the highest content of $\mathrm{C}_{\mathrm{fLF}}$ and $\mathrm{N}_{\mathrm{fLF}}$ is found in mor humus (130.55 and $5.31 \mathrm{~g} \mathrm{~kg}^{-1}$ respectively). $\mathrm{C}_{\mathrm{fLF}}$ and $\mathrm{N}_{\mathrm{fLF}}$ content in the third, deepest horizon of the tested humus types did not differ statistically. $\mathrm{C}_{\mathrm{oLF}}$ was significantly higher $(p<0.05)$ in the surface horizon of mull humus type; it was $13.65 \mathrm{~g} \mathrm{~kg}^{-1}$ on average. In the remaining humus types, the surface horizons contained lower amounts of $\mathrm{C}_{\mathrm{oLF}}$ (0.68-3.86 $\mathrm{g} \mathrm{kg}^{-1}$ on average). Second horizons of all tested humus types were characterized by a similar $\mathrm{C}_{\mathrm{oLF}}$ content (7.46-13.87 $\mathrm{g} \mathrm{kg}^{-1}$ on average) $(p>0.05)$. In the deepest horizons, the $\mathrm{C}_{\mathrm{oLF}}$ value range turned out to be even more similar between all types of humus (3.54$4.64 \mathrm{~g} \mathrm{~kg}^{-1}$ ). Similar regularities concerned the $\mathrm{N}_{\mathrm{oLF}}$ content. The mineral-associated fraction carbon content $\left(\mathrm{C}_{\mathrm{MAF}}\right)$ was more variable. The highest $\mathrm{C}_{\mathrm{MAF}}$ content characterized all horizons of mull humus type (average 20.44-24.66 $\left.\mathrm{g} \mathrm{kg}^{-1}\right)(p<0.05)$. In the second horizon, significantly lower $\mathrm{C}_{\mathrm{MAF}}$ content characterized Ah horizon of moder and moder-mull humus type (3.42 and $3.98 \mathrm{~g} \mathrm{~kg}^{-1}$, respectively). In the deepest horizons of mor, moder, and moder-mull humus, the mean $\mathrm{C}_{\mathrm{MAF}}$ content was 4.74-10.21 $\mathrm{g} \mathrm{kg}^{-1}$ and did not differ statistically significantly (Table 2 ). The $\mathrm{N}_{\mathrm{MAF}}$ content exhibited similar regularity to that of $\mathrm{C}_{\mathrm{MAF}}$.

Geo-accumulation index $\left(I_{\text {geo }}\right)$ for $\mathrm{Cr}, \mathrm{Mn}$, and $\mathrm{Ni}$, in the majority of analyzed horizons were ascribed values $<0$ which according to the scale proposed by Müller (1979) identifies the soils as not contaminated, for these metals. In the case of Mn, only in mull humus, the $I_{\text {geo }}$ mean values were 0.86 to 1.36 , suggesting unpolluted to moderately polluted and moderately polluted ranges. The $I_{\text {geo }}$ indices calculated for $\mathrm{Cu}$ in surface horizons of mor and moder humus type, for $\mathrm{Cd}$ in mor, moder, and moder-mull humus, as well as for $\mathrm{Zn}$ in mor, modermull, and mull humus remain in the range from 0 to 1 , suggesting classification of these under the lowest pollution ranges (unpolluted to moderately polluted). Only with regard to $\mathrm{Cd}$ in surface horizons of mull humus type and for $\mathrm{Pb}$ in mor, moder, and moder-mull humus type (Ah horizon), did the calculated mean $I_{\text {geo }}$ indices exceeded a value of 1 , which in accordance with the scale proposed by Müller (1979) enables classification of these soils as moderately polluted (Table S1). According to Sutherland scale (2000), values of enrichment factor $(\mathrm{EF})<2$ in the case of $\mathrm{Cr}, \mathrm{Ni}$ in the majority of horizons, and in the case of $\mathrm{Cu}$ and $\mathrm{Zn}$ as well as $\mathrm{Mn}$, with the exception for mull humus type, indicate soils with low pollution level. For $\mathrm{Cd}, \mathrm{Pb}$, and $\mathrm{Mn}$, the calculated mean values of EF remain in the range 25 which indicates moderately polluted soils. Only in one case, at Ah horizon of moder, the mean $\mathrm{EF}$ value for $\mathrm{Pb}$ exceeded 5 suggesting heavy pollution (Table S1).

All metals, especially $\mathrm{Cd}$, positively correlated with the carbon of light fraction of soil organic matter in organic horizons. $\mathrm{Cr}, \mathrm{Cu}, \mathrm{Ni}$, and $\mathrm{Pb}$ content correlated with the carbon of light fraction of soil organic matter in mineral horizons. Carbon of occluded light fraction of soil organic matter strongly correlated with $\mathrm{Cr}, \mathrm{Cu}, \mathrm{Ni}$, $\mathrm{Pb}$, and $\mathrm{Zn}$ in organic horizons and with all metals in mineral horizons. Carbon of heavy fraction of soil organic matter strongly correlated with $\mathrm{Cr}, \mathrm{Cu}$, and $\mathrm{Pb}$ content in organic horizons and with $\mathrm{Cd}, \mathrm{Cr}, \mathrm{Mn}$, and $\mathrm{Zn}$ in mineral horizons (Table 3). No correlation was found between enzymatic activity (DH, UR), and heavy metals (Table 4). The activity of the enzymes assayed correlated positively with carbon and nitrogen content (Table 4). Multiple regression analysis confirmed relationships between heavy metal content and the carbon content of soil organic matter fractions. Multiple regression models explained from 82 to $94 \%$ of the variance in the heavy metals content (Table 5). A projection of the variables on the factor plane clearly demonstrated correlations between the heavy metals content, fraction of soil organic matter, biochemical properties, and type of humus (Fig. 1). Depending on the horizon, two main factors had a significant total impact on the variance, from 62.17 to $80.68 \%$. Mull humus types are dominated by carbon of heavy fraction of soil organic matter $\left(\mathrm{C}_{\mathrm{MAF}}\right)$. Mor and moder humus types are dominated by light 
Table 3 Correlations between heavy metals and carbon of soil organic matter fraction

\begin{tabular}{|c|c|c|c|c|c|c|c|}
\hline \multicolumn{8}{|c|}{ Organic horizons } \\
\hline & $\mathrm{Cd}$ & $\mathrm{Cr}$ & $\mathrm{Cu}$ & $\mathrm{Mn}$ & $\mathrm{Ni}$ & $\mathrm{Pb}$ & $\mathrm{Zn}$ \\
\hline $\mathrm{C}_{\mathrm{LF}}$ & $0.586^{*}$ & -0.459 & -0.288 & -0.332 & -0.495 & -0.358 & 0.429 \\
\hline $\mathrm{C}_{\mathrm{oF}}$ & -0.101 & $0.876^{*}$ & $0.929 *$ & -0.393 & $0.616^{*}$ & $0.942 *$ & $0.673 *$ \\
\hline $\mathrm{C}_{\mathrm{MAF}}$ & -0.024 & $0.816^{*}$ & $0.850 *$ & $-0.689 *$ & 0.493 & $0.855^{*}$ & $0.623 *$ \\
\hline \multicolumn{8}{|c|}{ Mineral horizons } \\
\hline & $\mathrm{Cd}$ & $\mathrm{Cr}$ & $\mathrm{Cu}$ & $\mathrm{Mn}$ & $\mathrm{Ni}$ & $\mathrm{Pb}$ & $\mathrm{Zn}$ \\
\hline $\mathrm{C}_{\mathrm{LF}}$ & 0.007 & $0.569 *$ & $0.836^{*}$ & -0.249 & $0.771^{*}$ & $0.873 *$ & 0.322 \\
\hline $\mathrm{C}_{\mathrm{oF}}$ & $0.648 *$ & $0.745^{*}$ & $0.439 *$ & $0.483 *$ & $0.491 *$ & $0.650 *$ & $0.745 *$ \\
\hline $\mathrm{C}_{\mathrm{MAF}}$ & $0.765^{*}$ & $0.438 *$ & -0.408 & $0.921 *$ & -0.019 & -0.270 & $0.661 *$ \\
\hline
\end{tabular}

fraction of soil organic matter (fLF and oLF). The first horizon of mull humus is associated with high content of $\mathrm{Mn}, \mathrm{Cd}$, and $\mathrm{Co}$, and the first horizon of moder and mor humus is related with $\mathrm{Cu}, \mathrm{Ni}$, and $\mathrm{Pb}$ content (Fig. 1). In the deeper horizon of examined humus types $(\mathrm{Oh}, \mathrm{Ah}$, and A), relations with metals are different. The second horizon of mull humus is associated with a high content of $\mathrm{Mn}$, and the remaining metals are most accumulated in the second horizon of mor humus (Fig. 1). In the lowest lying horizons of the examined humus types (AE and $\mathrm{AB}$ ), heavy metals strongly correlated with the carbon of the heavy fraction of soil organic matter. Deeper horizons of mull humus types were characterized by the highest content of $\mathrm{C}$ in the MAF fraction which resulted in a high content of heavy metals (Fig. 1). There was no clear relationship between microbial biomass of $\mathrm{C}$ and $\mathrm{N}$ and heavy metal content (Fig. 1).

\section{Discussion}

Soils were found to have high levels of contamination with $\mathrm{Pb}$ and $\mathrm{Cd}$. The concentration of these metals in the surface horizons of the tested soils exceeds maximum allowable concentration (MAC) of trace elements (Kabata-Pendias 2011). The calculated index $I_{\text {geo }}$ and $\mathrm{EF}$ confirmed soil pollution with $\mathrm{Cd}$ and $\mathrm{Pb}$ and the tested soils have been classified as moderately polluted. Concentrations of the remaining tested metals did not exceed maximum allowable concentration of trace elements. According to Wilcke et al. (1996), accumulation of $\mathrm{Cd}, \mathrm{Pb}$, and $\mathrm{Cu}$ is facilitated by high concentration of organic carbon in the surface soil horizons. All humus types differed in the accumulation of heavy metals, which can be linked to the variable concentration of organic matter remaining at a different decay class. Egli et al. (1999) suggest that distribution of $\mathrm{Pb}, \mathrm{Cd}$, and $\mathrm{Zn}$ in forest soil was determined by the decomposition of organic matter.

\subsection{Humus Type Determines the Heavy Metal Accumulation}

For mor, moder, and moder-mull humus, higher accumulation of $\mathrm{Pb}$ was found in the subsurface horizons compared to the surface soils. Given the $\mathrm{Pb}$ is found in deeper layers in the profile, it is likely the origin of this $\mathrm{Pb}$ dates back to earlier industrial activity, rather than current practice. Within the area covered by the study, the degree of pollutant deposition has been reduced due to the closure or modernization of most polluting industrial plants (Magiera et al. 2015).

Humic substances have the capacity to interact with metal ions, which make them important agents for

Table 4 Correlations between enzymes activity and chemical properties

\begin{tabular}{llllllllllllll}
\hline & $\mathrm{pH} \mathrm{H} 2 \mathrm{O}$ & $\mathrm{pH} \mathrm{KCl}$ & $\mathrm{N}$ & $\mathrm{C}$ & $\mathrm{C} / \mathrm{N}$ & $\mathrm{Zn}$ & $\mathrm{Cd}$ & $\mathrm{Pb}$ & $\mathrm{Cu}$ & $\mathrm{Ni}$ & $\mathrm{Cr}$ & $\mathrm{Mn}$ \\
\hline $\mathrm{UR}$ & $-0.381 *$ & $-0.368^{*}$ & $0.563 *$ & $0.539^{*}$ & -0.099 & 0.236 & 0.203 & 0.136 & 0.306 & $0.679 *$ & 0.171 & -0.111 \\
$\mathrm{DH}$ & 0.147 & 0.032 & $0.462 *$ & $0.393^{*}$ & $-0.456^{*}$ & 0.317 & 0.273 & 0.019 & 0.078 & 0.239 & 0.109 & 0.173 \\
\hline
\end{tabular}

$* p<0.05$ 
Table 5 Multiple regression analysis for heavy metal based on chemical properties

\begin{tabular}{|c|c|c|c|c|}
\hline Heavy metal & $R^{2}$ & Equation parameter & $\beta$ & $p$ \\
\hline \multirow[t]{3}{*}{$\mathrm{Zn}$} & \multirow[t]{3}{*}{0.94} & $\mathrm{C}_{\mathrm{oLF}}$ & 3.1723 & 0.0000 \\
\hline & & $\mathrm{C}_{\mathrm{fLF}}$ & 0.2413 & 0.0000 \\
\hline & & $\mathrm{C}_{\mathrm{MAF}}$ & 1.5086 & 0.0000 \\
\hline \multirow[t]{3}{*}{$\mathrm{Cd}$} & \multirow[t]{3}{*}{0.89} & $\mathrm{C}_{\mathrm{MAF}}$ & 0.0347 & 0.0000 \\
\hline & & $\mathrm{C}_{\mathrm{fLF}}$ & 0.0028 & 0.0000 \\
\hline & & $\mathrm{C}_{\mathrm{oLF}}$ & 0.0335 & 0.0013 \\
\hline \multirow[t]{2}{*}{$\mathrm{Pb}$} & \multirow[t]{2}{*}{0.85} & $\mathrm{C}_{\mathrm{oLF}}$ & 7.8321 & 0.0000 \\
\hline & & $\mathrm{C}_{\mathrm{fLF}}$ & 0.2446 & 0.0000 \\
\hline \multirow[t]{2}{*}{$\mathrm{Cu}$} & \multirow[t]{2}{*}{0.82} & $\mathrm{C}_{\mathrm{oLF}}$ & 1.6766 & 0.0000 \\
\hline & & $\mathrm{C}_{\mathrm{fLF}}$ & 0.0915 & 0.0000 \\
\hline \multirow[t]{3}{*}{$\mathrm{Ni}$} & \multirow[t]{3}{*}{0.86} & $\mathrm{pH} \mathrm{H}_{2} \mathrm{O}$ & 1.0082 & 0.0099 \\
\hline & & $\mathrm{C}_{\mathrm{fLF}}$ & 0.0467 & 0.0000 \\
\hline & & $\mathrm{C}_{\mathrm{oLF}}$ & 0.5250 & 0.0042 \\
\hline \multirow[t]{3}{*}{$\mathrm{Cr}$} & \multirow[t]{3}{*}{0.91} & $\mathrm{C}_{\mathrm{oLF}}$ & 1.3724 & 0.0000 \\
\hline & & $\mathrm{C}_{\mathrm{fLF}}$ & 0.0497 & 0.0000 \\
\hline & & $\mathrm{C}_{\mathrm{MAF}}$ & 0.4695 & 0.0003 \\
\hline \multirow[t]{2}{*}{$\mathrm{Mn}$} & \multirow[t]{2}{*}{0.84} & $\mathrm{C}_{\mathrm{MAF}}$ & 34.4169 & 0.0000 \\
\hline & & $\mathrm{C}_{\mathrm{fLF}}$ & -0.6933 & 0.0242 \\
\hline
\end{tabular}

$\overline{R^{2} \text { describes the percentage of explained variance, } \beta \text { is the regres- }}$ sion coefficient for given equation parameter and $p$ is the significance level for the equation parameter

speciation and mobility of metals in soils (Donisa et al. 2003; Xiong et al. 2015). According to these authors for $\mathrm{Pb}, \mathrm{Cu}, \mathrm{Zn}$, and $\mathrm{Cd}$, the association with the fulvic fraction is dominant. The number of heavy metals leached from soil largely depends on the soil $\mathrm{pH}$ and for $\mathrm{Ni}, \mathrm{Cu}, \mathrm{Zn}, \mathrm{Cd}$, and $\mathrm{Pb}$, it greatly increases in the $\mathrm{pH}$ ranges $<4$ and $>8$ (Dijkstra et al. 2004). The mor, moder, and moder-mull soils are characterized by strongly acidic $\mathrm{pH}$, which undoubtedly favors metal leaching process. It is probable that the lower concentration of metals in the surface horizons of the soils is a result of leaching to deeper horizons. Deverel et al. (2011) suggest that low $\mathrm{pH}$ and formation of soluble organic complexes can result in increased mobility and leaching to deeper horizons.

4.2 Heavy Metal Accumulation Is Associated with Soil Organic Matter Fractions

Accumulation of heavy metals ( $\mathrm{Co}, \mathrm{Cr}, \mathrm{Cu}, \mathrm{Pb}$, and $\mathrm{Zn}$ ) in horizons of the analyzed humus types is strongly associated with carbon of occluded light fraction $\left(\mathrm{C}_{\mathrm{oLF}}\right)$ and with carbon of mineral-associated fraction $\left(\mathrm{C}_{\mathrm{MAF}}\right)$. The higher content of these fractions, the higher the accumulation of the mentioned metals, which would indicate the considerable importance of these fractions in metal binding. The geochemical mobility of toxic metals in soils depends on how and which soil phase they are bound to and their chemical form (Giacalone et al. 2005). In mineral horizons of the tested humus types, all heavy metals exhibited a clear positive association with the amount of $\mathrm{C}_{\mathrm{oLF}}$, whereas the strongest relationship with $\mathrm{C}_{\mathrm{MAF}}$ was shown by the concentration of $\mathrm{Cd}, \mathrm{Co}, \mathrm{Mn}$, and $\mathrm{Zn}$. In previous work, Błońska (2015) analyzed mineral humic horizons of beech and oak-hornbeam stands in the reserves of Polish lowlands. This work demonstrated that heavy metals exhibit a strong association with occluded light fraction carbon $\left(\mathrm{C}_{\mathrm{oLF}}\right)$ in those soils. Metals may form bridging complexes with organic coatings on mineral surfaces; additionally, metal-organic ligand complexes, formed in solution, are also liable to be adsorbed by soil surfaces (Staunton 2002). Organic-mineral interactions in soil reach from weak contact occlusion to strong chemical bonds formed by complexation reaction (von Lützow et al. 2007). The central atom of complex humic substances (usually a metal atom) joins ligands, i.e., active groups of humus compounds, or simple organic compounds (Pastuszko 2007). Occlusion inside aggregates may strongly affect the composition and dynamics of soil organic material (Buurman and Roscoe 2011) and indirectly on metals mobility.

\subsection{Heavy Metals Do Not Inhibit Enzyme Activity in the Different Humus Types}

Our third hypothesis on the influence of heavy metals on the biochemical activity in different humus types in forest soil was not supported. There was no relationship between enzymatic activity and heavy metals concentration. However, a strong positive correlation between enzymes activity and carbon content was found. It is likely that the soil organic matter masked any negative impact of metals on the activity of dehydrogenases and urease. Numerous studies indicate that organic matter reduces the toxicity of heavy metals in relation to enzymatic activity (de Mora et al. 2005; Karaca et al. 2006; Błońska et al. 2016; Pająk et al. 2016). According to Karaca et al. (2010), soil characteristics such as pH, clay content, and soil organic matter can modify the impacts of heavy metals on soil enzymes. 

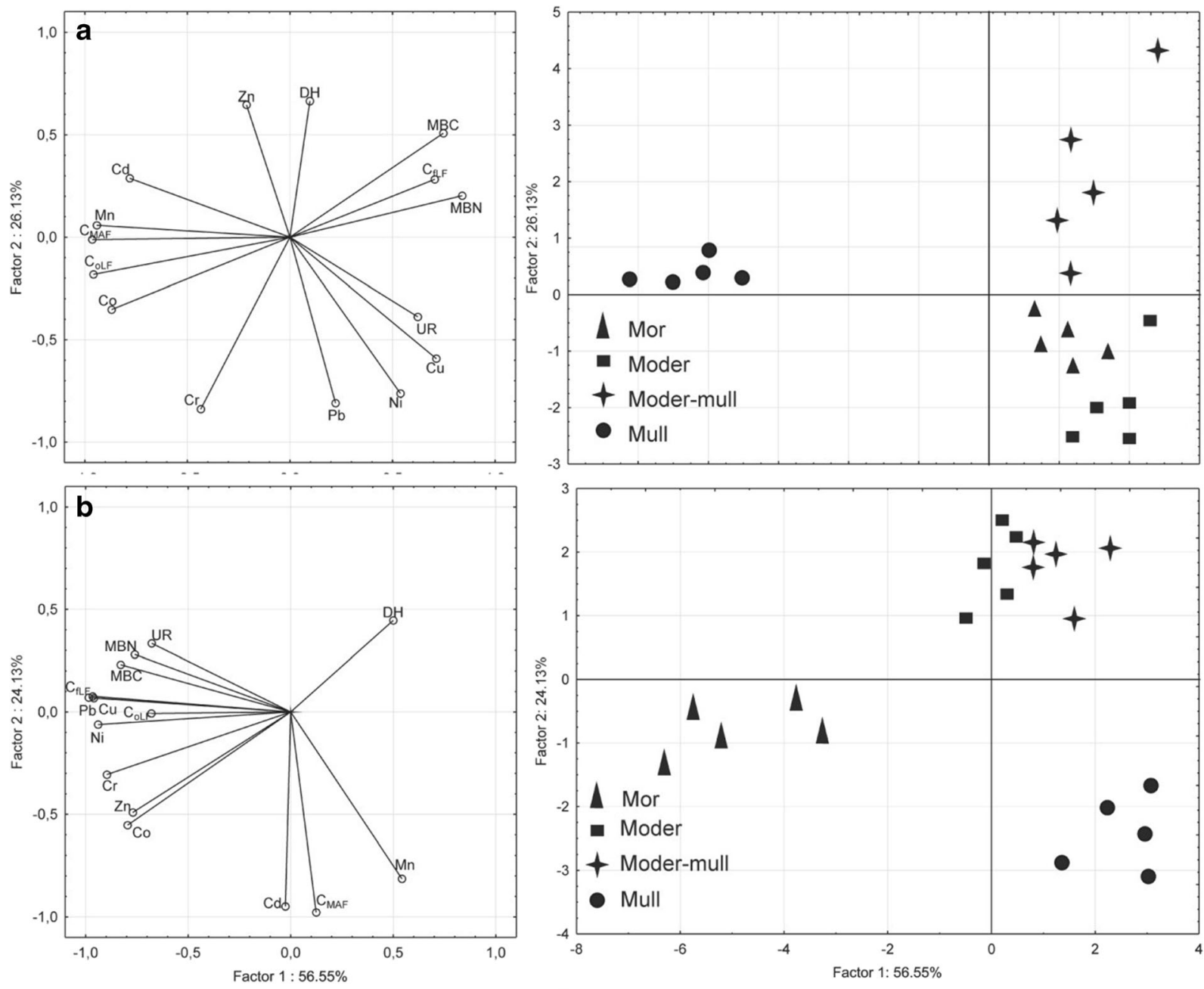

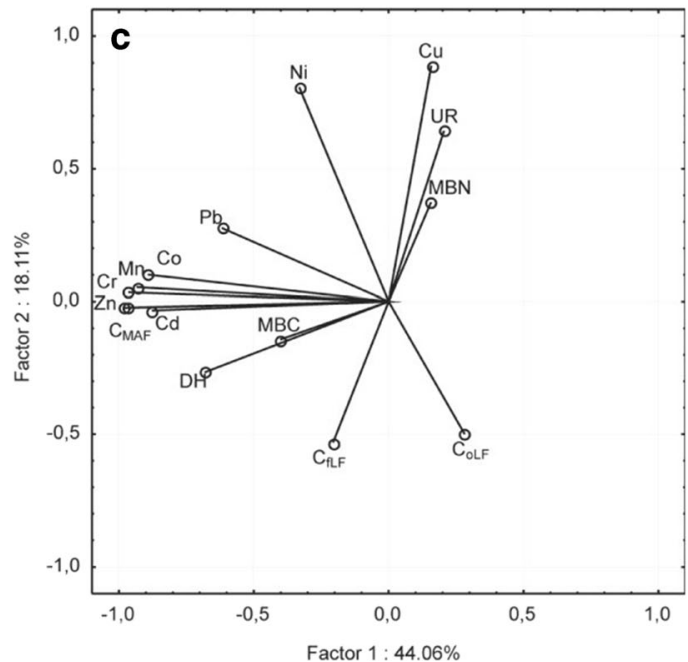

Fig. 1 Projection of the variables on the factor plane. a First horizon of different humus types. b Second horizon of different humus types. c Third horizon of different humus types. $\mathrm{C}_{\mathrm{fLF}}$ carbon of free light fraction, $\mathrm{C}_{\mathrm{oLF}}$ carbon of occluded light

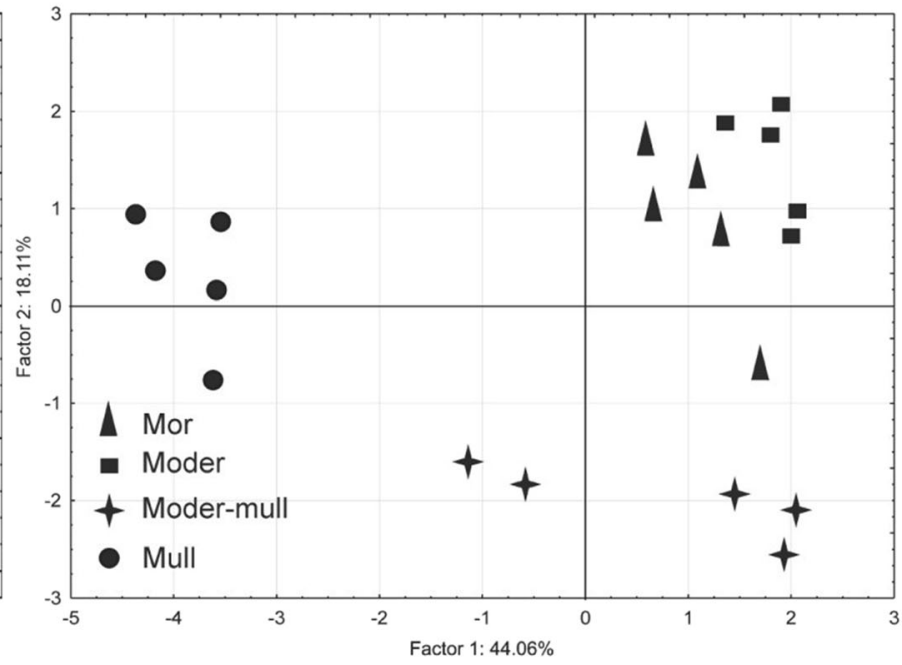

fraction, $\mathrm{C}_{\mathrm{MAF}}$ carbon of mineral associated fraction, $\mathrm{DH}$ dehydrogenase activity, UR urease activity, MBC carbon microbial biomass, MBN nitrogen microbial biomass 
Soil organic matter influences metal binding and their impact on soil microorganisms (Kuźniar et al. 2018; Wolińska et al. 2018). Bioavailability constitutes an important factor in the assessment of metal toxicity (Vig et al. 2003). Angle et al. (1993) believe that total metal content in soil is not a sufficient measure of their impact on microorganisms. Absence of toxicity in soils defined as heavily polluted may be linked to the fact that soils contain metals in forms and structures of limited bioavailability (Siebielec et al. 2006). In our current study, the strong relationship of heavy metals with organic matter resulted in their reduced availability. Moreover, within the study area, deposition was strongest in years 1970-2000, now much diminished. In 1980, the annual deposition of technogenic particulates was $35 \mathrm{~g} /$ $\mathrm{m}^{2}$, in $199945 \mathrm{~g} / \mathrm{m}^{2}$, and in $20133.2 \mathrm{~g} / \mathrm{m}^{2}$ (Magiera et al. 2015). The order-of-magnitude reduction of aerial deposition is clearly reflected in the $I_{\text {geo }}$ and EF indices.

Exogenous metals deposited into the soil are subject to aging reactions, translating into a reduction of their mobility over time (Lock and Janssen 2003). In addition, multi-annual deposition of pollutants has resulted in the development of certain adaptive mechanisms by microorganisms in soils polluted with metals. Pollution with heavy metals results in changes in microorganism population structures, but do not reduce their general activity (Palmborg and Nordgren 1996; Harris-Hellal et al. 2009; Azarbad et al. 2016; Kuźniar et al. 2018).

A positive correlation between urease activity and nickel concentration was found in our soils. Earlier research has demonstrated that lower nickel concentrations have a stimulatory effect on urease activity, while higher nickel concentrations have an inhibitory effect (Pérezurria et al. 1986). Metals detected in small amounts in the soil are not harmful and can even stimulate certain enzyme processes (Błońska et al. 2016). Urease is an enzymatic protein containing nickel bound within the active site necessary for the synthesis of the protein molecule (Balicka and Varanka 1978). We therefore posit that there may be a biogeochemical link between nickel deposition and the production of soilborne urease in these forest soils.

\section{Conclusions}

Our findings support two out of three research hypotheses. We confirmed that the humus type of forest soils determines the accumulation of heavy metals. The humus types are characterized by variability of properties, especially soil organic matter content and $\mathrm{pH}$ which significantly influences the mobility and potential availability of heavy metals. The accumulation of heavy metals in the humus types is strongly associated with carbon of occluded light fraction $\left(\mathrm{C}_{\mathrm{oLF}}\right)$ and with carbon of mineralassociated fraction $\left(\mathrm{C}_{\mathrm{MAF}}\right)$, to a lesser extent with carbon of free light fraction $\left(\mathrm{C}_{\mathrm{fLF}}\right)$. We rejected the third hypothesis on the limiting influence of heavy metals on the biochemical activity in different humus types in forest soil. We suggest that organic matter masks the negative impact of metals on the enzyme activity.

Funding Information This research was financed by the Ministry of Science and Higher Education of the Republic of Poland and from the Scholarship Fund of the University of Agriculture for funding a scientific internship abroad.

\section{Compliance with Ethical Standards}

Conflict of Interest The authors declare that they have no conflict of interest.

Open Access This article is licensed under a Creative Commons Attribution 4.0 International License, which permits use, sharing, adaptation, distribution and reproduction in any medium or format, as long as you give appropriate credit to the original author(s) and the source, provide a link to the Creative Commons licence, and indicate if changes were made. The images or other third party material in this article are included in the article's Creative Commons licence, unless indicated otherwise in a credit line to the material. If material is not included in the article's Creative Commons licence and your intended use is not permitted by statutory regulation or exceeds the permitted use, you will need to obtain permission directly from the copyright holder. To view a copy of this licence, visit http://creativecommons.org/licenses/by/4.0/.

\section{References}

Alef, K., \& Nannipieri, P. (1995). Enzyme activities. In P. Nannipieri \& K. Alef (Eds.), Methods in applied soil microbiology and biochemistry pp (pp. 311-375). London: Academic Press.

Azarbad, H., van Gestel, C. A. M., Niklińska, M., Laskowski, R., Röling, W. F., \& van Straalen, N. M. (2016). Resilience of soil microbial communities to metals and additional stressors: DNA-based approaches for assessing "stress-on-stress" responses. International Journal of Molecular Sciences, 17(6), 933.

Baaru, M.W., Mungendi, D.N., Bationo, A., Verchot, L., \& Waceke, W. (2007). Soil microbial biomass carbon and nitrogen as influenced by organic and inorganic inputs at 
Kebete, Kenya. In: Batiano A. (eds.) Advances in integrated soil fertility management in Sub- Saharan Africa: challenges and oppurtunities, pp 827-832.

Balicka, N., \& Varanka, M. W. (1978). Effect of industrial pollution of air on soil microflora. Advances of Agricultural Sciences Problem Issues, 206, 17-27.

Błońska, E. (2015). Effect of stand species composition on the enzyme activity and organic matter stabilization in forest soil; scientific papers of University of Agriculture in Krakow no. 527; University of Agriculture in Krakow: Kraków, Poland, volume 404.

Błońska, E., Lasota, J., Szuszkiewicz, M., Łukasik, A., \& Klamerus-Iwan, A. (2016). Assessment of forest soil contamination in Krakow surroundings in relation to the type of stand. Environment and Earth Science, 75(16), 1-15.

Błońska, E., Lasota, J., \& Gruba, P. (2017). Enzymatic activity and stabilization of organic matter in soil with different detritus inputs. Journal of Soil Science and Plant Nutrition, 63, 242-247.

Brookes, P. C. (1995). The use of microbial parameters in monitoring soil pollution by heavy metals. Biology Fretility of Soils, 19, 269-279.

Buurman, P., \& Roscoe, R. (2011). Different chemical composition of free light, occluded light and extractable SOM fractions in soils of Cerrado and tilled and untilled fields, Minas Gerais, Brazil: a pyrolysis-GC/MS study. European Journal of Soil Science, 62, 253-266.

de Mora, A. P., Ortega-Calvo, J. J., Gabrera, F., \& Madejon, E. (2005). Changes in enzyme activities and microbial after "in situ" remediation of a heavy metal-contaminated soil. Applied Soil Ecology, 28, 125-137.

Deverel, S. J., Goldberg, S., \& Fujii, R. (2011). Chemistry of trace elements in soils and groundwater. Chapter 4. In W. W. Wallender \& K. K. Tanji (Eds.), Agricultural salinity assessment and management. American Society of Civil Engineers.

Dijkstra, J. J., Meeussen, J. C. L., \& Comans, R. N. J. (2004). Leaching of heavy metals from contaminated soils: An experimental and modeling study. Environmental Science and Technology, 38(16), 4390-4395.

Donisa, C., Mocanu, R., \& Steinnes, E. (2003). Distribution of some major and minor elements between fulvic and humic acid fractions in natural soils. Geoderma, 111, 75-84.

Dube, A., Zbytniewski, R., Kowalkowski, T., Cukrowska, E., \& Buszewski, B. (2001). Adsorption and migration of heavy metals in soil. Polish Journal of Environmental Studies, 10(1), 1-10.

Duddigan, S., Shaw, L. J., Alexander, P. D., \& Collins, C. D. (2019). A comparison of physical soil organic matter fractionation methods for amended soils. Applied and Environmental Soil Science. https://doi.org/10.1155 /2019/383124.

Egli, M., Fitze, P., \& Oswald, M. (1999). Changes in heavy metal contents in an acidic forest soil affected by depletion of soil organic matter within the time span 1969-93. Environmental Pollution, 105, 367-379.

Falkowski, P. G., Fenchel, T., \& Delong, E. F. (2008). The microbial engines that drive Earth's biogeochemical cycles. Science, 320, 1034-1039.

Giacalone, A., Gianguzza, A., Orecchion, S., Piazzese, D., Dongarrà, G., Sciarrino, S., \& Varrica, D. (2005). Metals distribution in the organic and inorganic fractions of soil: a case study on soils from Sicily. Chemical Speciation \& Biovailabilty, 17, 83-93.

Gougoulias, C., Clark, J. M., \& Shaw, L. J. (2014). The role of soil microbes in the global carbon cycle: tracking the belowground microbial processing of plant-derived carbon for manipulating carbon dynamics in agricultural systems. Journal of the Science of Food and Agriculture, 94(12), 2362-2371.

Grüneberg, E., Schöning, I., Hessenmöller, D., Schulze, E. D., \& Weisser, W. W. (2013). Organic layer and clay content control soil organic carbon stocks in density fractions of differently managed German beech forests. Forest Ecology and Management, 303, 1-10.

Harris-Hellal, J., Vallaeys, T., Garnier-Zarli, E., \& Bousserrrhine, N. (2009). Effects of mercury on soil microbial communities in tropical soils of French Guyana. Applied Soil Ecology, 41, 59-68.

Impellitteri, C. A., Lu, Y., Saxe, J. K., Allen, H. E., \& Peijnenburg, W. J. G. M. (2002). Correlation of the partitioning of dissolved organic matter fractions with the desorption of $\mathrm{Cd}, \mathrm{Cu}$, $\mathrm{Ni}, \mathrm{Pb}$ and $\mathrm{Zn}$ from 18 Dutch soils. Environmental International, 28, 401-410.

Kabata-Pendias, A. (2011). Trace elements in soils and plants (4th ed.). New York: Taylor and Francis.

Karaca, A., Turgay, C., \& Tamer, N. (2006). Effects of a humic deposit (Gyttja) on soil chemical and microbiological properties and heavy metal availability. Biology and Fertility of Soils, 42, 585-592.

Karaca, A., Cetin, S. C., Turgay, O. C., \& Kizilkaya, R. (2010). Effects of heavy metals on soil enzyme activities. In I. Sherameti \& A. Varma (Eds.), Soil heavy metals, soil biology. Berlin: Springer-Verlag.

Karczewska, A., \& Kabała, C. (2010). The soil polluted with heavy metals and arsenic in Lower Silesia - the need and methods of reclamation. Zeszyty Naukowe UP Wroclaw, Rolnictwo, 96(576), 59-80.

Kelepertzis, E. (2014). Accumulation of heavy metals in agricultural soils of Mediterranean: insights from Argolida basin, Peleponese, Greece. Geoderma, 221-222, 82-90.

Kuźniar, A., Banach, A., Stępniewska, Z., Frąc, M., Oszust, K., Gryta, A., Kłos, M., \& Wolińska, A. (2018). Communitylevel physiological profiles of microorganisms inhabiting soil contaminated with heavy metals. International Agrophysics, $32,101-109$.

Lasota, J., \& Błońska, E. (2013). Forest site science in the polish lowlands and highlands; scientific papers. Kraków: University of Agriculture in Krakow.

Lee, J. S., Kim, O. K., Chang, Y. Y., Bae, B., Kim, H. H., \& Baek, H. H. (2002). Heavy metal concentrations and enzyme activities in soil from a contaminated Korean shooting range. Journal of Bioscience and Bioengeering, 94(5), 406-411.

Li, X., Volger, I., \& Schwendenmann, L. (2019). Soil aggregation and soil fraction associated carbon under different vegetation types in a complex landscape. Soil Research, 57(3), 215-227.

Lock, K., \& Janssen, C. R. (2003). Influence of aging on metal availability in soils. Reviews of Environmental Contamination and Toxicology, 178, 1-21.

Magiera, T., Parzentny, H., Róg, L., Chybiorz, R., \& Wawer, M. (2015). Spatial variation of soil magnetic susceptibility in relation to different emission sources in southern Poland. Geoderma, 255-256, 94-103. 
Magiera, T., Parzentny, H., \& Łukasik, A. (2016). The influence of the wind direction and plants on the variability of topsoil magnetic susceptibility in industrial and urban areas of southern Poland. Environment and Earth Science, 75, 213.

Marrugo-Negrete, J., Pinedo-Hermández, J., \& Díez, S. (2017). Assessment of heavy metal pollution, spatial distribution and origin in agricultural soils along the Sinú River Basin, Colombia. Environmental Research, 154, 380-388.

Marschner, B., Brodowski, S., Dreves, A., Gleixner, G., Gude, A., Grootes, P., Hamer, U., Heim, A., Jandl, G., Ji, R., Kaiser, K., Kalbitz, K., Kramer, C., Leinweber, P., Rethemeyer, J., Schäffer, A., Schmidt, M. W. I., Schwark, L., \& Wiesenberg, G. L. B. (2008). How relevant is recalcitrance for the stabilization of organic matter in soils? Journal of Plant Nutrition and Soil Science, 171, 91-110. https://doi. org/10.1002/jpln.200700049.

Müller, G. (1979). Schwermetalle in den sedimenten des RheinseVeranderungen seitt 1971. Umschau, 778-783.

Osman, K. (2013). Organic matter of forest soils. In: Forest Soils. Springer, Cham.

Ostrowska, A., Gawlinski, S., \& Szczubiałka, Z. (1991). Methods of analysis and assessment of soil and plant properties. Warszawa: Environmental Protection Institute (in Polish).

Pająk, M., Błońska, E., Frąc, M., \& Oszust, K. (2016). Functional diversity and microbial activity of forest soils that are heavily contaminated by lead and zinc. Water, Air, and Soil Pollution, $227,348$.

Palmborg, C., \& Nordgren, A. (1996). Partitioning the variation of microbial measurements in forest soil into heavy metal and substrate quality dependent parts by use of near infrared spectroscopy and multivariate statistics. Soil Biology and Biochemistry, 28, 711.

Pansu, M., \& Gautheyrou, J. (2006). Handbook of soil analysis. Mineralogical, Organic and Inorganic Methods. SpringerVerlag, Berlin Heidelberg, p. 993.

Pastuszko, A. (2007). Soil organic matter. Environmental Protection Natural Research, 30, 83-98.

Pérezurria, E., Legaz, M. E., \& Vicente, C. (1986). The function of nickel on the urease activity of the lichen Evernia Prunastri. Plant Science, 43, 37-43.

Quenea, K., Lamy, I., Winterton, P., Bermond, A., \& Dumat, C. (2009). Interactions between metals and soil organic matter in various particle size fractions of soil contamined with waste water. Geoderma, 1, 217-223.

Siebielec, G., Stuczyński, T., \& Korzeniowska-Pucułek, R. (2006). Metal bioavailability in long-term contaminated Tarnowskie Góry soils. Polish Journal of Environmental Studies, 15, 121-129.

Smołka-Danielowska, D. (2006). Heavy metals in fly ash from a coal-fired power station in Poland. Polish Journal of Environmental Studies, 15, 943-946.

Sohi, S. P., Mahieu, N., Arah, J. R. M., Madari, B., \& Gaunt, J. L. (2001). A procedure for isolating soil organic matter fractions suitable for modeling. Soil Science Society of America Journal, 65, 1121-1128.

Staunton, S. (2002). Direct and indirect effects of organic matter on metal immobilization in soil. In A. Violante, P. M. Huang,
J.-M. Bollag, \& L. Gianfreda (Eds.), Developments in soil science (Vol. 28A, pp. 79-97). Elsevier Science B.V..

Sutherland, R. A. (2000). Bed sediment-associated trace metals in an urban stream, Oahu, Hawaii. Environmental Geology, 39, 611-627.

Tabatabai, M. A., \& Bremner, J. M. (1972). Assay of urease activity in soils. Soil Biology and Biochemistry, 4, 479-487.

Tóth, G., Hermann, T., Da Silva, M. R., \& Montanarella, L. (2016). Heavy metals in agricultural soils of the European Union with implications for food safety. Environment International, 88, 299-309.

Vance, E. D., Brookes, P. C., \& Jenkinson, D. S. (1987). An extraction method for measuring soil microbial biomass $\mathrm{C}$. Soil Biology and Biochemistry, 19, 703-707.

Vig, K., Megharaj, M., Senthunathan, N., \& Naidu, R. (2003). Bioavailability and toxicity of cadmium to microorganisms and their activities in soil: a review. Advances in Environmental Research, 8, 121-135.

von Lützow, M., Kögel-Knabner, I., Ekschmitt, K., Flessa, H., Guggenberger, G., Matzner, E., \& Marschner, B. (2007). SOM fractionation methods: relevance to functional pools and to stabilization mechanisms. Soil Biology and Biochemistry, 39, 2183-2207.

Wambsganss, J., Stutz, K. P., \& Lang, F. (2017). European beech deadwood can increase soil organic carbon sequestration in forest topsoils. Forest Ecology and Management, 405, 200-209.

Wang, X. S. (2008). Correlations between heavy metals and organic carbon extracted by dry oxidation procedure in urban roadside soils. Environmental Geology, 54, 269-273.

Wang, Y. P., Shi, J. Y., Wang, H., Lin, Q., Chen, X. C., \& Chen, Y. $X$. (2007). The influence of soil heavy metals pollution on soil microbial biomass, enzyme activity, and community composition near a copper smelter. Ecotoxicology and Environmental Safety, 67, 75-81.

Wilcke, W., Baumler, R., Deschauer, H., Kaupenjohann, M., \& Zech, W. (1996). Small scale distribution of Al, heavy metals, and PAHs in an aggregated Alpine Podzol. Geoderma, 71, 19-30.

Wolińska, A., Banach, A., Szafranek-Nakonieczna, A., Stępniewska, Z., \& Błaszczyk, M. (2018). Easily degradable carbon - an indicator of microbial hotspots and soil degradation. International Agrophysics, 32, 123-131.

WRB (World Reference Base For Soil Resource). (2014). FAO, ISRIC and ISSS.

Xiong, J., Koopal, L. K., Weng, L., Wang, M., \& Tan, W. (2015). Effect of soil fulvic and humic acid on binding of $\mathrm{Pg}$ to goethite-water interface: linear additivity and volume fractions of HS in the stern layer. Journal of Colloid and Interface Science, 457, 121-130.

Zaiets, O., \& Poch, R. M. (2016). Micromprphology of organic matter and humus in Mediterranean mountains soils. Geoderma, 272, 83-92.

Publisher's Note Springer Nature remains neutral with regard to jurisdictional claims in published maps and institutional affiliations. 